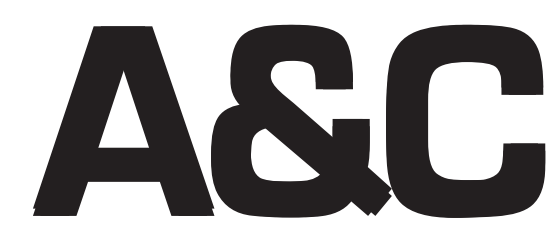

Revista de Direito Administrativo \& Constitucional

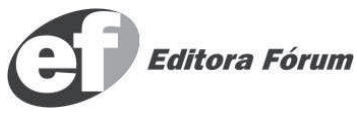

ISSN 1516-3210 


\section{A\&C REVISTA DE DIREITO ADMINISTRATIVO \& CONSTITUCIONAL}

\section{IPDA}

Instituto Paranaense

de Direito Administrativo

Direção Geral

Romeu Felipe Bacellar Filho

Direção Editorial

Paulo Roberto Ferreira Motta

Direção Executiva

Emerson Gabardo

Conselho de Redação

Edgar Chiuratto Guimarães

Adriana da Costa Ricardo Schier

Célio Heitor Guimarães

\section{Conselho Editorial}

Adilson Abreu Dallari (Brasil) Alice Gonzales Borges (Brasil) Antonello Tarzia (Itália)

Carlos Ari Sundfeld (Brasil)

Carlos Ayres Britto (Brasil)

Carlos Delpiazzo (Uruguai)

Cármen Lúcia Antunes Rocha (Brasil)

Celso Antônio Bandeira de Mello

(Brasil)

Clèmerson Merlin Clève (Brasil)

Clovis Beznos (Brasil)

Enrique Silva Cimma (Chile)

Eros Roberto Grau (Brasil)

Fabrício Motta (Brasil)

Guilhermo Andrés Muñoz - in memoriam

(Argentina)

Jaime Rodríguez-Arana Muñoz (Espanha)

Jorge Luís Salomoni - in memoriam
(Argentina)
José Carlos Abraão (Brasil)
José Eduardo Martins Cardoso (Brasil)
José Luís Said (Argentina)
José Mario Serrate Paz (Uruguai)
Juan Pablo Cajarville Peruffo (Uruguai)
Juarez Freitas (Brasil)
Julio Rodolfo Comadira - in memoriam
(Argentina)
Luís Enrique Chase Plate (Paraguai)
Lúcia Valle Figueiredo (Brasil)
Manoel de Oliveira Franco Sobrinho -
in memoriam (Brasil)
Marçal Justen Filho (Brasil)
Marcelo Figueiredo (Brasil)

\author{
Maria Cristina Cesar de Oliveira (Brasil) \\ Nelson Figueiredo (Brasil) \\ Odilon Borges Junior (Brasil) \\ Pascual Caiella (Argentina) \\ Paulo Eduardo Garrido Modesto (Brasil) \\ Paulo Henrique Blasi (Brasil) \\ Paulo Neves de Carvalho - in memoriam \\ (Brasil) \\ Paulo Ricardo Schier (Brasil) \\ Pedro Paulo de Almeida Dutra (Brasil) \\ Regina Maria Macedo Nery Ferrari (Brasil) \\ Rogério Gesta Leal (Brasil) \\ Rolando Pantoja Bauzá (Chile) \\ Sérgio Ferraz (Brasil) \\ Valmir Pontes Filho (Brasil) \\ Weida Zancaner (Brasil) \\ Yara Stropa (Brasil)
}

A246 A\&C Revista de Direito Administrativo \& Constitucional. ano 3, n. 11, jan./mar. 2003. Belo Horizonte: Fórum, 2003.

Trimestral

ano 1, n. 1, 1999 até ano 2, n. 10, 2002 publicada pela Editora Juruá em Curitiba

ISSN 1516-3210

1. Direito Administrativo. 2. Direito Constitucional. I. Fórum.

CDD: 342

CDU: 33.342

(C) 2008 Editora Fórum Ltda.

Todos os direitos reservados. É proibida a reprodução total ou parcial, de qualquer forma ou por qualquer meio eletrônico ou mecânico, inclusive através de processos xerográficos, de fotocópias ou de gravação, sem permissão por escrito do possuidor dos direitos de cópias (Lei nº 9.610, de 19.02.1998).

Editora Fórum Ltda

Editor responsável: Luís Cláudio Rodrigues Ferreira

Av. Afonso Pena, 2770 - 15\%16ªndar - Funcionários

CEP 30130-007 - Belo Horizonte/MG - Brasil

Coordenação editorial: Olga M. A. Sousa

Tel.: 08007043737

Internet: www.editoraforum.com.br

Pesquisa jurídica: Fátima Ribeiro - OAB/MG 74868

Revisora: Lourdes Nascimento

Projeto gráfico e diagramação: Luis Alberto Pimenta

e-mail: editoraforum@editoraforum.com.br

Bibliotecária: Fernanda de Paula Moreira - CRB 2900 - 6a região

Esta publicação está indexada no Ulrich's Periodicals Directory

Os conceitos e opiniões expressas nos trabalhos assinados são de responsabilidade exclusiva de seus autores.

Impressa no Brasil / Printed in Brazil

Distribuída em todo o Território Nacional 


\title{
Incompatibilidade da aplicação da Lei de Improbidade Administrativa com a prerrogativa de função dos Conselheiros do Tribunal de Contas
}

\begin{abstract}
Mauro Roberto Gomes de Mattos
Advogado no Rio de Janeiro. Autor dos livros (dentre outros): O contrato administrativo. 2. ed. Rio de Janeiro: América Jurídica, 2002; O Limite da improbidade administrativa: o direito dos administrados dentro da Lei n 8.429/92. 2. ed. rev. atual. e ampl. Rio de Janeiro: América Jurídica, 2005; Lei $n^{\circ} 8.112 / 90$ interpretada e comentada: regime jurídico único dos servidores públicos da união. 2. ed. rev. ampl. e atual. Rio de Janeiro: América Jurídica, 2005; Tratado de direito administrativo disciplinar. Rio de Janeiro: América Jurídica, 2008. Vice-Presidente do Instituto IberoAmericano de Direito Público (Capítulo Brasileiro) - IADP. Co-Coordenador da Revista Ibero-Americana de Direito Público - RIADP (Órgão de Divulgação Oficial do IADP).
\end{abstract}

Resumo: Neste artigo aborda-se a incompatibilidade da aplicação da Lei de Improbidade Administrativa com a prerrogativa de função dos Conselheiros do Tribunal de Contas. Primeiramente são tratados aspectos gerais da Lei de Improbidade Administrativa frente aos princípios constitucionais. Analisa-se, em seguida, o acórdão da Reclamação no 2.138 do STF, demonstrando que o regime jurídico aplicável aos Ministros do Tribunal de Contas da União é equiparado ao dos membros da magistratura. Afirma-se que aos Conselheiros do Tribunal de Contas se aplica a LC n ${ }^{\circ} 35 / 79$ no que couber, elencando-se as hipóteses que podem ocasionar a perda dos seus respectivos cargos. Sustenta-se que, havendo violação da moralidade, o Conselheiro do Tribunal de Contas responderá por crime de responsabilidade e não nos termos da Lei de Improbidade, por possuir prerrogativas de função. Conclui-se que essa incompatibilidade com a Lei de Improbidade Administrativa não gera ou cria impunidade jurídica, visto que os Conselheiros do Tribunal de Contas responderão por crimes de responsabilidade.

Palavras-chave: Lei de Improbidade. Conselheiros do Tribunal de Contas. Incompatibilidade. Prerrogativa de função. Crime de responsabilidade. Moralidade.

Sumário: 1 Introdução - 2 Atos de improbidade administrativa descritos na Lei $\mathrm{n}^{\mathrm{o}}$ 8.429/92 constituem autênticos crimes de responsabilidade 3 Conclusão

\section{Introdução}

A Lei de Improbidade Administrativa tem como origem o combate aos atos públicos que afetem a probidade e a moralidade, dentre outros relevantes princípios constitucionais, e maltratem a coisa pública, através da prática de situações estabelecidas de forma devassa e com prejuízo ao erário.

Para tanto, o artigo $37, \S 4^{\circ}$ da CF, estabeleceu que os atos de improbidade administrativa importarão a suspensão dos direitos políticos,

A\&C R. de Dir. Administrativo \& Constitucional, Belo Horizonte, ano 8, n. 33, p. 33-46, jul./set. 2008 
a perda da função pública, a indisponibilidade dos bens e o ressarcimento ao erário, na forma e gradações previstas em lei, "sem prejuízo da ação penal cabivel" (g.n.).

Ou seja, a Constituição Federal se preocupou em estimular o combate à corrupção moral e financeira que sempre assolou o nosso país, por parte de alguns agentes públicos.

A fim de atender ao citado preceito constitucional elencado no artigo $37, \S 4^{\circ}$, foi editada a Lei $\mathrm{n}^{\circ} 8.429 / 92$, com a finalidade de tipificar a prática dos atos de improbidade administrativa, bem como os seus sujeitos ativos.

Nesse sentido, o artigo inaugural da Lei $n^{\circ} 8.429 / 92$ preconiza que os atos de "improbidade praticados por qualquer agente público servidor ou não contra a Administração Direta, indireta ou fundacional de qualquer dos Poderes" estariam, em tese, subsumidos na citada Lei Federal.

Por agente público, a própria Lei de Improbidade Administrativa, em seu artigo $2^{\circ}$, descreveu que são todos aqueles que exercem mandato, cargo, emprego ou função em entes de direito público.

Ou seja, a lei sub examem estabelece que agente público é toda pessoa que exerce, permanente ou transitoriamente, com ou sem remuneração, por eleição, nomeação, designação, contratação ou qualquer outra forma de investidura ou vínculo, mandato, cargo, emprego ou função pública.

Também, de forma ampla, a Lei Bilac Pinto (Lei no 3.502, de 21 de dezembro de 1958), que antecedeu à Lei ${ }^{\circ}$ 8.429/92, designou a figura do servidor público como o destinatário de seus comandos legais.

Houve, dessa forma, uma ampliação do conceito de "servidor público" para o de "agente público", com a finalidade de que a atual Lei de Improbidade Administrativa pudesse abranger os objetivos da própria Constituição Federal.

Os "agentes públicos" estabelecidos pela Lei no 8.429/92 são os servidores do Estado e pessoas coletivas de direito público, constituindo o elemento humano dos serviços públicos, quando entendidos entes em sentido lato.

Chegamos a afirmar em outra oportunidade:1 "São abrangidos não só os agentes de serviços públicos, como os agentes políticos, pessoal contratado, servidores militares, enfim, a Lei de Improbidade abrange, de uma forma ampla, todos os que direta ou indiretamente se relacionam

MATTOS, Mauro Roberto Gomes de. O Limite da Improbidade Administrativa: o direito dos administrados dentro da Lei n 8.429/92. 3. ed. Rio de Janeiro: América Jurídica, 2006. p. 16.

A\&C R. de Dir. Administrativo \& Constitucional, Belo Horizonte, ano 8, n. 33, p. 33-46, jul./set. 2008 
com o Poder Público, com o objetivo de não deixar ninguém excluído do campo de ação das sanções que ela dispõe."

Portanto, segundo a Lei de Improbidade Administrativa, o conceito agente público genericamente abrange a todas as pessoas que executam funções públicas, até mesmo transitoriamente. Não resta dúvida de que nessa condição jurídica de "agente público", se inserem os Magistrados, os Membros do Tribunal de Contas e os Agentes Políticos, entre outros.

Todas as três categorias nominadas, segundo o que vem estabelecido na Lei $n^{\circ} 8.429 / 92$ estão inseridas em seu escopo e, segundo a citada norma, se praticarem, no exercício de suas funções, ou em razão delas, atos administrativos que importem em enriquecimento ilícito (artigo $9^{\circ}$, da Lei $n^{\circ} 8.429 / 92$ ), prejuízo ao erário (artigo 10, da Lei no 8.429/92), violação aos bons princípios da Administração Pública (art. 11, da Lei no 8.429/92) responderão pela prática de ato de improbidade administrativa, em tese.

Essa situação era relativamente tranqüila, tanto na doutrina, como na jurisprudência, visto que, incorrendo em atos de improbidade administrativa, o agente público está sujeito, independentemente de outras penalidades na esfera penal, administrativa e cível, às sanções previstas no artigo 12, da Lei $\mathrm{n}^{\circ}$ 8.429/92.

Para tanto, basta a subsunção da conduta do agente público em um dos três tipos infracionais da Lei ${ }^{\circ}$ 8.429/92, já declinados.

Sucede que, apesar de possuir natureza civil, a Lei $n^{\circ}$ 8.429/92, não afasta os aspectos penais incidentes. Isso porque, mesmo a Lei de Improbidade Administrativa possuindo natureza administrativa e política, há também a conotação penal, como dito por Arnoldo Wald e Gilmar Ferreira Mendes, ${ }^{2}$ ao atualizarem a obra de Hely Lopes Meirelles: "é inegável que a chamada ação de improbidade administrativa tem cunho civil (ressalvados, obviamente, os aspectos criminais da Lei $\mathrm{n}^{\circ}$ 8.429/92, a serem perseguidos em ação penal própria, que não se confunde com a ação civil de improbidade, aqui abordada). (...) Tais características, no entanto, fazem da ação de improbidade administrativa uma ação civil de forte conteúdo penal, e com inegáveis aspectos políticos”.

Partindo da premissa de que a Lei de Improbidade possui "forte conteúdo penal" em suas sanções, quando utilizadas com a finalidade de punir o agente público pela prática de qualquer dos atos tipificados como

\footnotetext{
2 MEIRELLES, Hely Lopes. Mandado de segurança. Atualizado por Arnoldo Wald e Gilmar Ferreira Mendes. 28. ed. São Paulo: Malheiros, 2005. p. 215.
}

A\&C R. de Dir. Administrativo \& Constitucional, Belo Horizonte, ano 8, n. 33, p. 33-46, jul./set. 2008 
ímprobos, houve, através da Reclamação no 2.138/STF o questionamento quanto ao conflito da citada Lei Federal com as garantias estabelecidas pela Constituição Federal para os agentes políticos, detentores de mandatos.

Apesar de o STF não ter analisado a situação jurídica dos Magistrados e dos Membros dos Tribunais de Contas, o princípio é o mesmo adotado pela Reclamação $n^{\circ}$ 2.138/STF, tendo em vista que esses agentes públicos devem se submeter a regimes distintos de responsabilidade, em face das prerrogativas que lhes são conferidas para o exercício de suas relevantes funções. Um Juiz que não possua a garantia mínima de sua independência funcional não possui liberdade para decidir contendas judiciais, visto que ele será um meio aplicador da lei, sujeitando-se, por óbvio, em decorrência da situação em que se encontra a proferir julgamentos políticos. Da mesma forma, os Conselheiros dos Tribunais de Contas, que são responsáveis pelos julgamentos administrativos das regularidades das contas dos entes públicos federais, estaduais, municipais e do Distrito Federal, se não possuírem as mínimas garantias, serão figuras decorativas, deixando de zelar pelo princípio da economicidade quando do julgamento das contas públicas, para se vincularem a um sistema que lhes retiraria as suas garantias legais, quando investidos em suas relevantes funções.

Essas três altas funções (agente político, Magistrado e Conselheiro do Tribunal de Contas) são complexas e envolvem alguns desdobramentos constitucionais que, segundo o STF, para o caso específico dos agentes políticos, inviabiliza a aplicação integral da Lei $n^{\circ} 8.429 / 92$, quando se tratar da apuração da prática de ato de improbidade administrativa, porquanto a natureza jurídica das sanções cominadas na Lei ${ }^{\circ}$ 8.429/92, tais como a perda da função e a suspensão dos direitos políticos, possuem similitude com as sanções penais dispostas no Decreto no 201/67, que pune a prática de crimes de responsabilidade por Prefeitos Municipais, que somente poderiam ser aplicados pelos Tribunais de Justiça dos Estados (artigo 29, X, da CF).

Constituindo crimes de responsabilidade, a prática do ato de improbidade administrativa, a que alude a Lei $\mathrm{n}^{\circ} 8.429 / 92$, colide com outras normas constitucionais e legais, de grau hierárquico superior.

Assim sendo, a prerrogativa de função retira a incidência da Lei $\mathrm{n}^{\circ}$ 8.429/92, visto que os crimes de responsabilidade dos agentes políticos, dos Magistrados e dos Conselheiros dos Tribunais de Contas e dos membros do MP seguem orientações constitucionais que os retiram do contexto da Lei de Improbidade Administrativa.

A\&C R. de Dir. Administrativo \& Constitucional, Belo Horizonte, ano 8, n. 33, p. 33-46, jul./set. 2008 


\section{Atos de improbidade administrativa descritos na Lei $n^{\circ} 8.429 / 92$ constituem autênticos crimes de responsabilidade}

Após o julgamento da Reclamação no 2.138, o Supremo Tribunal Federal (STF), trouxe uma interessante e relevante discussão jurídica, visto que a maioria dos Ministros admitiu que os atos de improbidade administrativa descritos na Lei ${ }^{\circ}$ 8.429/92 constituem autênticos crimes de responsabilidade (cf. voto do Min. Gilmar Mendes na RC n ${ }^{\circ}$ 2.138/STF).

Rigorosamente nesse sentido, o Ministro Relator Nelson Jobim já havia se antecipado, quando do deferimento da medida liminar requerida na citada Reclamação no 2.138/STF, verbis: "Assim, em análise preliminar, não parece haver dúvida de que os delitos previstos da L. 1079, tais como os arrolados na L. 8429/92, são delitos políticos-administrativos. É certo que se a competência para processar e julgar a ação de improbidade (CF, art. $37, \S^{\circ}$ ) abranger também atos praticados pelos agentes políticos, submetidos a regime de responsabilidade especial, ter-se-á uma interpretação ab-rogante do disposto no art. 102, I, 'c', da Constituição. Se, ao contrário, se entender que aos agentes políticos como os Ministros de Estado, por estarem submetidos a um regime especial de responsabilidade, há que se afirmar a plena e exclusiva competência do STF para processar e julgar os delitos político-administrativos, na hipótese do art. 102, I, 'c', da Constituição. Conclui-se também, num juízo preliminar, que, na segunda hipótese, não se cuida de assegurar ao agente político um regime de imunidade em face dos atos de improbidade. O agente político há de responder pelos delitos de responsabilidade perante os órgãos competentes para processá-lo e julgá-lo."

Isso porque a natureza jurídica de algumas sanções cominadas pela Lei $n^{\circ}$ 8.429/92 (perda da função e suspensão dos direitos políticos) também são sanções penais dispostas na Lei $n^{\circ} 1.079 / 50$ ou Decreto $n^{\circ}$ 201/67 pela prática de crimes de responsabilidade, aos quais estão vinculados não só os agentes políticos, com também os membros do Poder Judiciário e os Conselheiros dos Tribunais de Contas, que só podem ser sancionados pelos Tribunais de Justiça dos Estados, ou dos Tribunais Superiores, dependendo de cada caso, em face do privilégio do foro ratione officii.

Ou seja, o crime de responsabilidade, como infração político-administrativa à qual se sujeitam os Conselheiros do Tribunal de Contas, tramitará no juízo competente, em virtude da instituição da prerrogativa de foro, estabelecida em função do cargo exercido.

A\&C R. de Dir. Administrativo \& Constitucional, Belo Horizonte, ano 8, n. 33, p. 33-46, jul./set. 2008 
Isso porque a Constituição Federal equiparou o regime jurídico dos Ministros do TCU aos da Magistratura (CF, art. 73, §3), estendendo tais garantias aos Tribunais de Contas dos Estados e dos Municípios (CF, art. 75).

Nesse sentido, aplicam-se aos Conselheiros dos Tribunais de Contas, no que couber, os dispositivos da Lei Complementar no 35, de 12.03.1979 (LOMAN).

Sendo que, depois de nomeados e empossados, os Conselheiros só perderão seus cargos por efeito de sentença judicial, exoneração a pedido, ou por motivo de incompatibilidade com o exercício de sua função.

Após uma interpretação sistemática entre as normas legais aplicáveis aos Conselheiros em Cortes de Contas com a LOMAN, tem-se que os mesmos somente perderão seus cargos, quando a hipótese for a de sentença judicial, em ação penal por crime infamante ou de responsabilidade (cf. artigo 25, da LC n ${ }^{\circ} 35 / 79$ ).

Essa garantia não deve ser encarada como um privilégio, pois tal qual os Magistrados, os Conselheiros dos Tribunais de Contas são responsáveis pelo julgamento da matéria afeta às suas competências, que são de ordem pública, tendo em vista que são responsáveis pelo controle da regularidade dos gastos públicos. O controle da legalidade da realização de qualquer despesa ou receita do poder público, abrangida nesse contexto a concessão de quaisquer benefícios fiscais, é um dos importantes controle efetuados pelos Tribunais de Contas.

Por essa razão, a responsabilidade do Conselheiro pela prática de atos omissivos ou comissivos efetivados em decorrência de sua função não é aferível através de ação de improbidade administrativa.

É de se registrar que a Lei no 8.429/92 não revogou a Lei Complemen$\operatorname{tar} n^{\circ} 35 / 79$, como não poderia, face ao princípio da hierarquia das leis.

Com efeito, o disposto no artigo 22, da Lei de Improbidade Administrativa, deve ser interpretada de modo a não conflitar com as disposições, tanto da Constituição Federal, quanto da LC no 35/79.

A interpretação a ser adotada na espécie é a sistemática, tendo em vista o critério orgânico que vigora em nosso ordenamento jurídico constitucional.

E em nome dessa interpretação sistemática não se pode olvidar que, para o exercício de tão importantes missões constitucionais, faz-se necessária a existência de certas garantias ao membro do Tribunal de Contas

A\&C R. de Dir. Administrativo \& Constitucional, Belo Horizonte, ano 8, n. 33, p. 33-46, jul./set. 2008 
que têm como foco conferir à instituição a necessária independência para o exercício da jurisdição, resguardando-a das pressões ou intromissões de outros Poderes.

Não se caracterizando, pois, os predicamentos das presentes garantias conferidas aos Conselheiros dos Tribunais de Contas como privilégios, mas como meios de assegurar seus livres desempenhos, de molde a preconizar a independência e autonomia das Cortes de Contas.

Dessa maneira, a lei estabeleceu a prerrogativa de função não só dos Conselheiros dos Tribunais de Contas, mas também dos Magistrados, dos Agentes Políticos e dos Membros do Ministério Público, como forma de dotá-los de prerrogativas indispensáveis ao exercício livre de seus misteres. Contudo, essa liberdade funcional não significa impunidade no desempenho de suas atribuições, tendo em vista que a probidade é uma norma de conduta impostergável.

Havendo violação da mesma, através da prática, no exercício da função, de atos ímprobos, o Conselheiro responderá por crime de responsabilidade e não pelos termos da Lei de Improbidade Administrativa, como decidido pelo STF na situação jurídica dos agentes políticos, que possuem as mesmas prerrogativas de funções dos Membros das Cortes de Contas.

A "perda de cargo" de Magistrado ou de Membro do Tribunal de Contas, segundo o elencado no art. 26, da LOMAN, não prevê a hipótese de "improbidade administrativa" (sequer em tese).

Considerando que pela Constituição Federal a disciplina do Estatuto da Magistratura, extensível aos Membros do Tribunal de Contas, exige Lei Complementar, a Lei de Improbidade Administrativa, sendo lei ordinária, por si só, não possui poderes para disciplinar tal sanção para Juízes ou para os Conselheiros das Cortes de Contas.

Agrega-se a tal situação jurídica o que vem estabelecido no art. 27 da LOMAN, que estabelece a competência originária para eventual "perda de cargo" de Magistrado, o Tribunal Regional Federal, para a hipótese de Juízes Federais, ou para o Tribunal de Justiça dos Estados, nas situações que envolvem Juízes estaduais ou Conselheiros de Cortes de Contas dos respectivos Estados ou Municípios, ou seja, jamais a primeira instância (Juiz Federal ou de Vara de Fazenda Pública) possui competência legal para impor sanção às categorias funcionais anteriormente declinadas.

Outra hipótese jurídica que se torna irrefutável é que lei ordinária (Lei n $\left.{ }^{\circ} 8.429 / 92\right)$ não é instrumento normativo apto a alterar jurisprudência

A\&C R. de Dir. Administrativo \& Constitucional, Belo Horizonte, ano 8, n. 33, p. 33-46, jul./set. 2008 
assente do Supremo Tribunal Federal, fundada direta e exclusivamente na interpretação da CF.

Sendo oportuno esclarecer que a Constituição Federal não outorgou a interpretação constitucional às leis ordinárias, visto que tal delegação foi direcionada para o STF.

Portanto, estabelecido pelo STF que o Agente Político não responde por ato de improbidade administrativa, tal orientação é extensiva tanto para os Magistrados, como para os Conselheiros dos Tribunais de Contas, em face de suas prerrogativas de funções.

Pensar diferente é defender a possibilidade de lei ordinária (Lei $n^{o}$ 8.429/92) limitar determinada inteligência da Constituição Federal (Crime de Responsabilidade), para estabelecer situação que, por si só, fere frontalmente o próprio plasmado da Magna Carta.

Por outro lado, merece destaque parte do laborioso voto do Ministro Relator Nelson Jobim, ao relatar a Reclamação no 2.138/STF: “Ora, se os atos de improbidade administrativa do Presidente da República são crimes de responsabilidade, a fortiori, as condutas funcionais de improbidade administrativa, definidas pela Lei $\mathrm{n}^{\circ}$ 8.429/92, têm a mesma natureza jurídica, ou seja, são crimes de responsabilidade, pois, se assim é quanto ao presidente da República, nada se justifique que sua natureza se transmude em razão apenas, da diferença da função pública exercida pelo agente público. Se assim não for, cair-se-á no ilogismo de se admitir que uma circunstância meramente acidental é capaz de mudar a essência das coisas. Porque ato de improbidade administrativa é, na sua essência, crime de responsabilidade (também denominado, quiçá com maior propriedade, de infração político-administrativa), praticável não só pelo Presidente da República, mas por todo e qualquer agente político, a Lei $\mathrm{n}^{\circ}$ 1.079/50 estendeu sua aplicação aos Ministros de Estado (art. 13), aos Ministros do Supremo Tribunal Federal (art. 39), ao Procurador-geral da República (art. 40), aos governadores e secretários dos estados-membros (art. 74), fazendo questão de repetir, relativamente a cada um deles, que procedimento incompatível com a dignidade, a honra e o decoro do cargo atenta contra a probidade da Administração e é crime de responsabilidade. Por se tratar de crime de responsabilidade, o processo e julgamento dos agentes públicos, sejam ou não agentes políticos, aos quais se imputa a autoria de ato de improbidade administrativa, hão de obedecer às regras de competência constitucionalmente fixadas. Assim, pelos atos de improbidade de praticar, porque

A\&C R. de Dir. Administrativo \& Constitucional, Belo Horizonte, ano 8, n. 33, p. 33-46, jul./set. 2008 
constitutivos de crime de responsabilidade, o Presidente da República há de ser processado e julgado pelo Senado Federal, mediante prévia licença da Câmara dos Deputados, nos termos do artigo 86 da Constituição Federal; os Ministros de Estado e os comandantes da Marinha, do Exército e da Aeronáutica, quando não se tratar de crime de responsabilidade conexo com o do Presidente da República, os ministros do próprio Supremo Tribunal Federal, os membros dos Tribunais Superiores, os ministros do Tribunal de Contas da União e os chefes de missão diplomática de caráter permanente serão processados e julgados, originariamente, pelo Supremo Tribunal Federal (art. 102, I, c, da Constituição Federal); os desembargados dos Tribunais de Justiça dos Estados e do Distrito Federal, os membros dos Tribunais de Contas dos Estados e do Distrito Federal, os juízes dos Tribunais Regionais Federais, dos Tribunais Regionais Eleitorais e do Trabalho, aos membros dos Conselhos ou Tribunais de Contas dos Municípios e membros do Ministério Público da União que oficiem perante Tribunais, quando a ele imputada a prática de ato de improbidade, ou seja, a prática de crime de responsabilidade deverão eles ser processados e julgados, originariamente, pelo Superior Tribunal de Justiça (art. 105, I, $a$, da Constituição Federal); os governadores dos estados e do Distrito Federal, pela Assembléia Legislativa, nos trilhos da Lei n ${ }^{\circ}$ 1.079/50, com a devida adequação ao texto constitucional vigente; os prefeitos e vereadores, pela Câmara Municipal, segundo regras estampadas nos artigos $4^{\circ}$ e $7^{\circ}$, respectivamente, do Decreto-lei $n^{\circ} 201$, de 27 de fevereiro de 1967. Obviamente, os agentes públicos que não têm foro por prerrogativa de função constitucionalmente fixado, serão processados e julgados por juiz de primeiro grau de jurisdição. Pode não ser o desejável por muitos, que desconfiam da eficácia sancionatória, quando se trata de foro por prerrogativa de função, mas legem habemus e urge cumprir a lei que nos rege, principalmente quando essa lei é a Constituição da República Federativa do Brasil. Seu descumprimento torna inviável o Estado de Direito Democrático. Por fim, cabe ressaltar a improbidade dos efeitos da sentença proferida em primeira instância que, além de ter decretado a suspensão dos direitos políticos de Ministro de Estado pelo prazo de 08 anos e a perda da função pública, condenou-o, ainda, a perda do cargo efetivo de Ministro de $1^{\text {a }}$ classe do Ministério das Relações Exteriores, por fatos ligados ao exercício de sua função ministerial. (...)"

Com o mesmo brilho e eloqüência jurídica, o Ministro Luiz Fux (Relator p/ acórdão), no REsp no 456.649/MG (STJ, 1 T., DJ, p. 237, 05

A\&C R. de Dir. Administrativo \& Constitucional, Belo Horizonte, ano 8, n. 33, p. 33-46, jul./set. 2008 
out. 2006), assim ementou: "Administrativo. Ação Civil Pública. Ex-Prefeito. Conduta omissiva. Caracterização de infração político administrativa. Decreto-Lei $n^{\circ}$ 201/67. Ato de improbidade administrativa. Lei no 8.429/92. Coexistência. Impossibilidade. Manutenção do acórdão recorrido. Voto divergente do Relator. 1. Hipótese em que a controvérsia a ser dirimida nos presentes autos cinge-se em definir se a conduta do ex-prefeito, consistente na negativa do fornecimento de informações solicitadas pela Câmara Municipal, pode ser enquadrada, simultaneamente, no Decreto-lei no 201/ 67 que disciplina as sanções por infrações político-administrativas, e na Lei $\mathrm{n}^{\circ}$ 8.429/92, que define os atos de improbidade administrativa. 2. Os ilícitos previstos na Lei $\mathrm{n}^{\circ}$ 8.429/92 encerram delitos de responsabilidade quando perpetrados por agentes políticos diferenciando-se daqueles praticados por servidores em geral. 3. Determinadas autoridades públicas não são assemelhados aos servidores em geral, por força do cargo por elas exercido, e, conseqüentemente, não se inserem na redução conceitual do art. $2^{\circ}$ da Lei $n^{\circ} 8.429 / 92$ ('Reputa-se agente público, para os efeitos desta lei, todo aquele que exerce, ainda que transitoriamente ou sem remuneração, por eleição, nomeação, designação, contratação ou qualquer outra forma de investidura ou vínculo, mandato, cargo, emprego ou função nas entidades mencionadas no artigo anterior'), posto encartados na lei que prevê os crimes de responsabilidade. 4 . O agente político exerce parcela de soberania do Estado e pour cause atuam com a independência inextensível aos servidores em geral, que estão sujeitos às limitações hierárquicas e ao regime comum de responsabilidade. 5. A responsabilidade do agente político obedece a padrões diversos e é perquirida por outros meios. A imputação de improbidade a esses agentes implica em categorizar a conduta como 'crime de responsabilidade', de natureza especial. 6. A Lei de Improbidade Administrativa admite no seu organismo atos de improbidade subsumíveis a regime jurídico diverso, como se colhe do art. $14, \S^{\circ}$ da lei 8.429/92 ('\$3 Atendidos os requisitos da representação, a autoridade determinará a imediata apuração dos fatos que, em se tratando de servidores federais, será processada na forma prevista nos arts. 148 a 182 da Lei $\mathrm{n}^{\mathrm{o}} 8.112$, de 11 de dezembro de 1990 e, em se tratando de servidor militar, de acordo com os respectivos regulamentos disciplinares.'), por isso que se infere excluída da abrangência da lei os crimes de responsabilidade imputáveis aos agentes políticos. 7. O Decreto-lei n. ${ }^{\circ}$ 201/67, disciplina os crimes de responsabilidade dos agentes políticos (prefeitos e vereadores),

A\&C R. de Dir. Administrativo \& Constitucional, Belo Horizonte, ano 8, n. 33, p. 33-46, jul./set. 2008 
punindo-a com rigor maior do que o da lei de improbidade. Na concepção axiológica, os crimes de responsabilidade abarcam os crimes e as infrações político-administrativas com sanções penais, deixando, apenas, ao desabrigo de sua regulação, os ilícitos civis, cuja transgressão implicam sanção pecuniária. 8. Conclusivamente, os fatos tipificadores dos atos de improbidade administrativa não podem ser imputados aos agentes políticos, salvo através da propositura da correspectiva ação por crime de responsabilidade. 9. O realce político-institucional do thema iudicandum sobressai das conseqüências das sanções inerentes aos atos ditos ímprobos, tais como a perda da função pública e a suspensão dos direitos políticos. 10. As sanções da ação por improbidade podem ser mais graves que as sanções criminais tout court, mercê do gravame para o equilíbrio jurídico-institucional, o que lhe empresta notável colorido de infração penal que distingue os atos ilícitos civis dos atos ilícitos criminais. 11. Resta inegável que, no atinente aos agentes políticos, os delitos de improbidade encerram crimes de responsabilidade e, em assim sendo, revela importância prática a indicação da autoridade potencialmente apenável e da autoridade aplicadora da pena. 12. A ausência de uma correta exegese das regras de apuração da improbidade pode conduzir a situações ilógicas, como aquela retratada na Reclamação 2138, de relatoria do Ministro Nelson Jobim, que por seu turno, calcou-se na Reclamação 591, assim sintetizada: 'A ação de improbidade tende a impor sanções gravíssimas: perda do cargo e inabilitação, para o exercício de função pública, por prazo que pode chegar a dez anos. Ora, se um magistrado houver de responder pela prática da mais insignificante das contravenções, a que não seja cominada pena maior que multa, assegura-se-lhe foro próprio, por prerrogativa de função. Será julgado pelo Tribunal de Justiça, por este Tribunal Supremo. Entretanto a admitir a tese que ora rejeito, um juiz de primeiro grau poderá destituir do cargo um Ministro do STF e impor-lhe pena de inabilitação para outra função por até dez anos. Vê-se que se está diante de solução que é incompatível como o sistema.' 13. A eficácia jurídica da solução da demanda de improbidade faz sobrepor-se a essência sobre o rótulo, e contribui para emergir a questão de fundo sobre a questão da forma. Consoante assentou o Ministro Humberto Gomes de Barros na Rcl 591: 'a ação tem como origem atos de improbidade que geram responsabilidade de natureza civil, qual seja aquela de ressarcir o erário, relativo à indisponibilidade de bens. No entanto, a sanção traduzida na suspensão dos direitos políticos tem

A\&C R. de Dir. Administrativo \& Constitucional, Belo Horizonte, ano 8, n. 33, p. 33-46, jul./set. 2008 
natureza, evidentemente, punitiva. É uma sanção, como aquela da perda de função pública, que transcende a seara do direito civil. A circunstância de a lei denominá-la civil em nada impressiona. Em verdade, no nosso ordenamento jurídico, não existe qualquer separação estanque entre as leis civis e as leis penais.' 14. A doutrina, à luz do sistema, conduz à inexorável conclusão de que os agentes políticos, por estarem regidos por normas especiais de responsabilidade, não se submetem ao modelo de competência previsto no regime comum da lei de improbidade. O fundamento é a prerrogativa pro populo e não privilégio no dizer de Hely Lopes Meirelles, verbis: 'Os agentes políticos exercem funções governamentais, judiciais e quase-judiciais, elaborando normas legais, conduzindo os negócios públicos, decidindo e atuando com independência nos assuntos de sua competência. São as autoridades públicas supremas do Governo e da Administração, na área de sua atuação, pois não são hierarquizadas, sujeitando-se apenas aos graus e limites constitucionais e legais da jurisdição. Em doutrina, os agentes políticos têm plena liberdade funcional, equiparável à independência dos juízes nos seus julgamentos, e, para tanto, ficam a salvo de responsabilização civil por seus eventuais erros de atuação, a menos que tenham agido com culpa grosseira, má-fé ou abuso de poder. (...) Realmente, a situação dos que governam e decidem é bem diversa da dos que simplesmente administram e executam encargos técnicos e profissionais, sem responsabilidade de decisão e opções políticas. Daí por que os agentes políticos precisam de ampla liberdade funcional e maior resguardo para o desempenho de suas funções. As prerrogativas que se concedem aos agentes políticos não são privilégios pessoais; são garantias necessárias ao pleno exercício de suas altas e complexas funções governamentais e decisórias. Sem essas prerrogativas funcionais os agentes políticos ficariam tolhidos na sua liberdade de opção e decisão ante o temor de responsabilização pelos padrões comuns da culpa civil e do erro técnico a que ficam sujeitos os funcionários profissionalizados (cit. p. 77)' (Direito administrativo brasileiro. 27. ed., p. 76). 15. Aplicar-se a Lei de Improbidade, cegamente, pode conduzir a situações insustentáveis enunciadas pelo voto preliminar do Ministro Jobim, assim descritos: a) o afastamento cautelar do Presidente da República (art. 20, par. único. da Lei 8.429/92) mediante iniciativa de membro do Ministério Público, a despeito das normas constitucionais que fazem o próprio processo penal a ser movido perante esta Corte depender da autorização por dois terços da Câmara dos Deputados

A\&C R. de Dir. Administrativo \& Constitucional, Belo Horizonte, ano 8, n. 33, p. 33-46, jul./set. 2008 
(CF, art. 102, I, b, c;c o art. 86, caput); ou ainda o seu afastamento definitivo, se transitar em julgado a sentença de primeiro grau na ação de improbidade que venha a determinar a cassação de seus direitos políticos e a perda do cargo: b) o afastamento cautelar ou definitivo do presidente do Congresso Nacional e do presidente da Câmara dos Deputados nas mesmas condições do item anterior, a despeito de o texto constitucional assegurar-lhes ampla imunidade material, foro por prerrogativa de função em matéria criminal perante o STF (CF, art. 102, I, b) e regime próprio de responsabilidade parlamentar (CF, art. 55, II); c) o afastamento cautelar ou definitivo do presidente do STF, de qualquer de seus membros ou de membros de qualquer Corte Superior, em razão de decisão de juiz de primeiro grau; d) o afastamento cautelar ou definitivo de Ministro de Estado, dos Comandantes das Forças Armadas, de Governador de Estado, nas mesmas condições dos itens anteriores; e) o afastamento cautelar ou definitivo do procuradorgeral em razão de ação de improbidade movida por membro do Ministério Público e recebida pelo juiz de primeiro grau nas condições dos itens anteriores. 16. Politicamente, a Constituição Federal inadmite o concurso de regimes de responsabilidade dos agentes políticos pela Lei de Improbidade e pela norma definidora dos Crimes de Responsabilidade, posto inaceitável bis in idem. 17. A submissão dos agentes políticos ao regime jurídico dos crimes de responsabilidade, até mesmo por suas severas punições, torna inequívoca a total ausência de uma suposta 'impunidade' deletéria ao Estado Democrático de Direito. 18. Voto para divergir do e. Relator e negar provimento ao recurso especial do Ministério Público do Estado de Minas Gerais, mantendo o acórdão recorrido por seus fundamentos.”

Esses firmes posicionamentos jurisprudenciais citados não geram ou criam impunidades jurídicas a determinados agentes públicos, visto que os mesmos responderão por crimes de responsabilidade se praticarem atos ilícitos no exercício de suas funções. Apenas preconizam o STF e o STJ, com apoio de parte da doutrina, a incompatibilidade da aplicação da Lei de Improbidade Administrativa com a prerrogativa da função de determinados agentes públicos, incluindo nesse contexto, por analogia, os Conselheiros do Tribunal de Contas.

\section{Conclusão}

Após todo o exposto, conclui-se que os Conselheiros dos Tribunais de Contas, quando exercem os seus fundamentais misteres, não estão sujeitos ao determinado na Lei $n^{\circ}$ 8.429/92, por possuírem prerrogativas de função.

A\&C R. de Dir. Administrativo \& Constitucional, Belo Horizonte, ano 8, n. 33, p. 33-46, jul./set. 2008 
Essa conclusão deflui da interpretação da Constituição Federal dada pelo Supremo Tribunal Federal.

Informação bibliográfica deste texto, conforme a NBR 6023:2002 da Associação Brasileira de Normas Técnicas (ABNT):

MATTOS, Mauro Roberto Gomes de. Incompatibilidade da aplicação da Lei de Improbidade Administrativa com a prerrogativa de função dos Conselheiros do Tribunal de Contas. A\&C Revista de Direito Administrativo \& Constitucional, Belo Horizonte, ano 8, n. 33, p. 33-46, jul./set. 2008. 